Journal of Animal and Veterinary Advances 11 (15): 2660-2664, 2012

ISSN: $1680-5593$

(C) Medwell Journals, 2012

\title{
Biodiversity of Nematodes in Potato Growing Areas of Ordu, Turkey
}

\author{
${ }^{1}$ Faruk Akyazi, ${ }^{2}$ Senol Yildiz, ${ }^{1}$ Ozbay Dede and ${ }^{1}$ Anil Firat Felek \\ ${ }^{1}$ Department of Plant Protection, Faculty of Agriculture, University of Ordu, Turkey \\ ${ }^{2}$ Department of Plant Protection, Faculty of Agriculture, Bingol University, Turkey
}

\begin{abstract}
A survey was conducted to investigate nematode biodiversity in three major potato growing areas, Aybasti, Kabatap and Korgan districts of Ordu province of Turkey in 2010. In the survey, a total of 24 soil samples were collected from potato fields belonging to these areas where the native ecotypes called Aybasti Beyazi and Aybasti Sarisi occur. The analysis of the soil samples collected from the rhizosphere of potato revealed the presence of 25 nematode taxa belonging to different trophic groups. Nine genera of plant parasitic group, 2 families and 9 genera of bacterivorous group, 3 genera of fungivore group, one genus of predator group and one order of omnivore group were allocated. The incidence and the abundance of the nematotes varied among the three areas. Pratylenchus and Tylenchus sp., seem to be the most widespread plant parasitic genera because they were both frequent on the potato throughout the three regions. Meloidogyne was found only in a sample of Korgan district with a $720 \mathrm{~J} 2 \mathrm{~s}$ abundance. The other taxa found were Helicotylenchus, Geocenamus, Paratylenchus, Psilenchus, Filenchus, Meloidogyne, Tylenchorhynchus, Rhabditidae, Monhysteridae, Cephalobus, Eucephalobus, Acrobeloides, Chiloplachus, Cervidellus, Acrobeles, Wilsonema, Plectus, Tripyla, Aphelenchoides, Aphelenchus, Ditylenchus, Mononchus sp. and Dorylaimida. Plant parasitic nematodes except Pratylenchus sp. were not found to be very wide-spread and abundant in the province. On the other hand, free-living nematodes which were considered to be the indicators of soil heath were found divers and abundant.
\end{abstract}

Key words: Nematodes, biodiversity incidence, abundance, Ordu, potato, Turkey

\section{INTRODUCTION}

Potato (Solanum tuberosum L.) is an important agricultural tuber crop of Turkey as grown throughout the other countries and one of the top ten commodities as production quantity of Turkey that is ranked 13th in worldwide potato production value. In Turkey, potato (4.397.710 ton) is the third commodity in quantity value after Wheat (20.600.000 ton) and Barley (7.300.000 ton). The Black sea region of Turkey possesses approximately $10 \%$ of total potato production of Turkey (Demir and Kadanali, 2010) and Ordu is the province in the Black sea region and ranked first for potato production in the region (Dede, 2004).

Nematodes are the most divers group of organisms in soil ecosystems and function in different ways as their trophic relations. Nematodes usually are easily distinguished by their mouth structure which is associated their food source Theoretically, all trophic groups or some of them can be observed in a single soil sample from any rhisophere at the same time. These are plant parasitic nematodes, bacterivorous nematodes, fungivourous nematodes, pretatory nematodes and omnivorous nematodes (Yeates et al., 1993).
After Bongers (1990), diversity and abundance of free living nematodes are associated with the health of soil fauna which serves in organic material decomposition and mineralization. More divers and abundant free-living nematode assemblages are related with healthy and productive ecosystems (Neher, 2001). On the other hand, plant parasitic nematodes are considered to be the cause of yield losses in the crop ecosystems as their virulens and abundance increases.

Plant parasitic nematodes are an important limiting factors in world potato production. Jensen et al. (1979) listed 68 nematodes species feed on potato plants worldwide. A number of different nematode pathogens attack potato by using interactions with other hosts or just alone in different threshold densities and cause economical yield losses (Olthof, 1989; Wheeler et al.,1994; Philis, 1997; Morgan et al., 2002; Vovlas et al., 2005). Little is known about plant parasitic nematodes affecting potato in Turkey and in the Black sea region. The plant parasitic nematode species associated with potato have been reported in Turkey and world scale. Kepenekci emphasized the species such as Globodera rostochiensis, G. pallida, Ditylenchus destructor Thorne, Meloidogyne sp., Ditylenchus dipsaci (Kuhn) Filipjev), Neotylenchus

Corresponding Author: Faruk Akyazi, Department of Plant Protection, Faculty of Agriculture, University of Ordu, Turkey 
vigissi (Skarbilovich) Goodey), Nacobbus aberrans (Thorne) Thorne and Allen), Pratylenchus, Trichodorus and Longidorus sp., as important nematode genera and species in potato production. Erdogus et al. (2010) reported Filenchus cylindricus, F. sandneri, Lelenchus leptosoma and Geocenamus uralensis from the potato fields as new species. Misirloglu and Ulutas (2011) reported that Kutahya, Usak, Isparta and Burdur potentially favorable for potato growing in terms of plant parasitic nematodes harmful on potatoes as (Globodera sp., Ditylenchus destructor Thorne, Ditylenchus dipsaci (Kuhn) Filipjev, Meloidogyne sp., in 2006-2008. In another investigation, Criconemella, Ditylenchus, Heterodera, Meloidogyne, Pratylenchus and Tylenchorhynchus sp. were reported among the plant parasitic nematodes asociated with potato (Mokbel et al., 2006).

Yildiz andElekcioglu (2011) and Yildiz(2012) studied nematode biodiversity in semi-arid Southeast Anatolian region in several ecosystems. They found that in major crops of the region, plant parasitic species were not serious threat in the region while free-living nematodes were well established and divers in wheat fields than cotton and pistachio cultures. However, there is a most no study in Black sea region on the free-living fauna of nematodes in Turkey.

By this study, both plant parasitic and free-living groups are investigated in potato growing areas for the first time in Turkey. The objective of this research is to investigate nematode biodiversity in major potato growin areas of Ordu province with emphasizing abundance and distribution of plant parasitic nematodes species associated with potato and diversity and state of freeliving nematode groups.

\section{MATERIALS AND METHODS}

The main materials of the study was soil samples collected from potato fields of Ordu province of Turkey in July of 2010 (Fig. 1). Soil samples collected from 24 potato fields that belong to 7, 8, 9 fields in Aybasti, Kabatas, Korgan, respectivelly. In these areas, the native ecotypes called Aybasti Beyazi and Aybasti Sarisi occur.

Soil samples were taken randomly, by sampling 10 or 12 points of a field depending on the size. The samples were taken from the rhizosphere of the potato plants at a depth of $5-30 \mathrm{~cm}$, using a shovel. Each soil sample was thoroughly mixed and $1 \mathrm{~kg}$ of sub-sample was taken from a composite soil samples.

The soil samples kept in polythene bags and properly labeled were brought to the University of Ordu Nematology Laboratory. Soil samples were stored at $4^{\circ} \mathrm{C}$ until used in refrigerator. Then, nematodes were extracted by using modified Bearmen funnel technique from the soil samples (Hooper, 1969). An aliquot of $100 \mathrm{~cm}^{3}$ soil from the main $1 \mathrm{~kg}$ mixed soil subsample was taken and used for the nematode extraction. Then nematodes are counted under light microscope and allocated to trophic groups to the genera level. Ordu is the province located $40^{\circ} 58^{\prime} 31.1682^{\prime \prime} \mathrm{N} 37^{\circ} 54^{\prime} 10.8126^{\prime \prime} \mathrm{E}$ in coordinates. Average

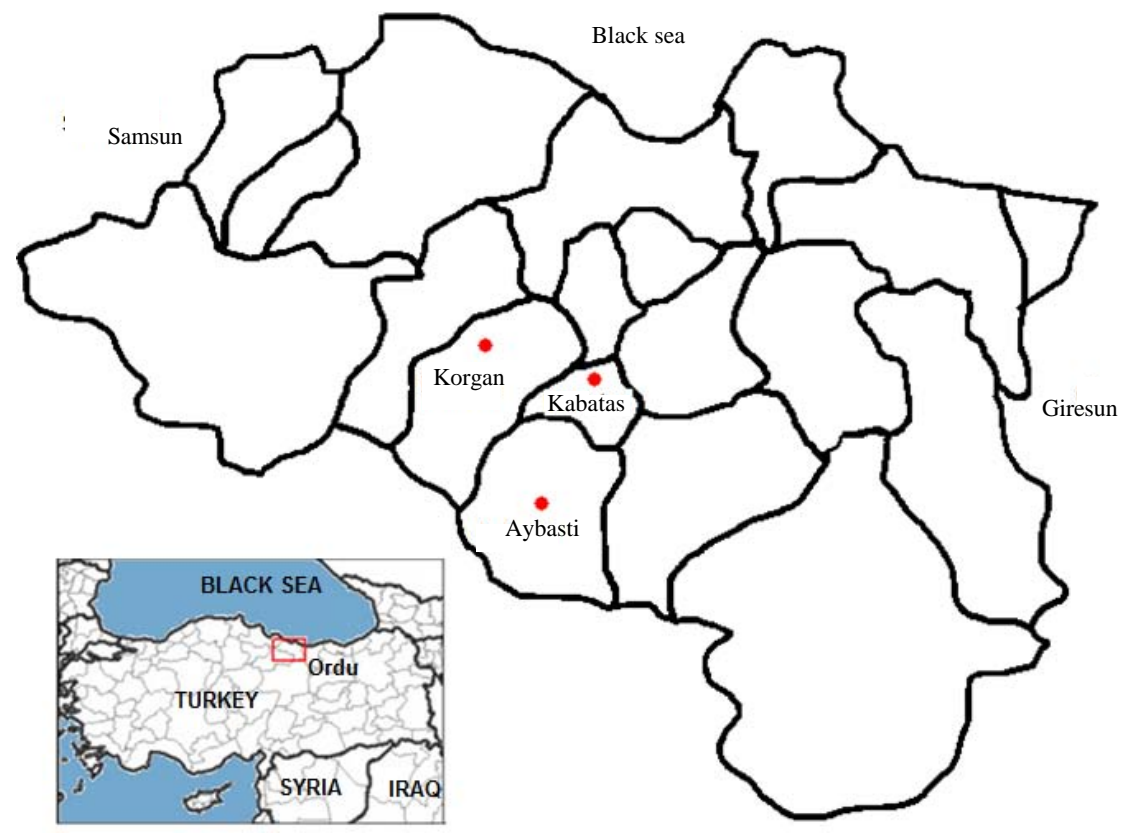

Fig. 1: The major potato growing areas sampled in Ordu province 
temperatures and total rainfall of 2010 and 2011 years, respectively are $16.6,14.4^{\circ} \mathrm{C}$ and 979.7 and $1369.4 \mathrm{~kg} \mathrm{~m}^{-2}$. Average elevations of Aybasti, Kabatas, Korgan are 697 . $702,1258 \mathrm{~m}$ above sea level, respectively. The climate is classified as a humid subtropical (no dry season, hot Summer) in the regions with a cool temperate moist forest biozone.

\section{RESULTS AND DISCUSSION}

Nematodes assemblages found in potato growing areas are shown in Fig. 2. Results suggest that the most abundant and divers trophic group is the bacterivores. Followed by fungivorous group, plant parasitic parasitic group and finally predator and omnivore groups (Fig. 2). One of the way to describe a nematode faunal composition is to look at its trophic structure. Trophic structure also gives a brief information about nematode faunal complex and its environment as the functional diversity in an ecosystem (Yeates, 1998).

The survey results indicated that Pratylenchus and Tylenchus sp. is the 1 st 2 widespread genera in the fields sampled. Pratylenchus sp. is the most abundant $\left(70,83 / 100 \mathrm{~cm}^{3}\right.$ soil) and frequent $(79.16 \%)$ genus in the entire study area. From the 24 fields sampled, nine genera of plant parasitic nematodes were found. The two genera
Pratylenchus and Tylenchus sp. were found in all three regions and the genus Meloidogyne were encountered in only Korgan district at high numbers (Table 1 and 2). Plant parasitic diversity was 9.7 and 4 genera in Korgan, Kabatas, Aybasti, respectively. The abundance of the most frequent genus Pratylenchus sp.

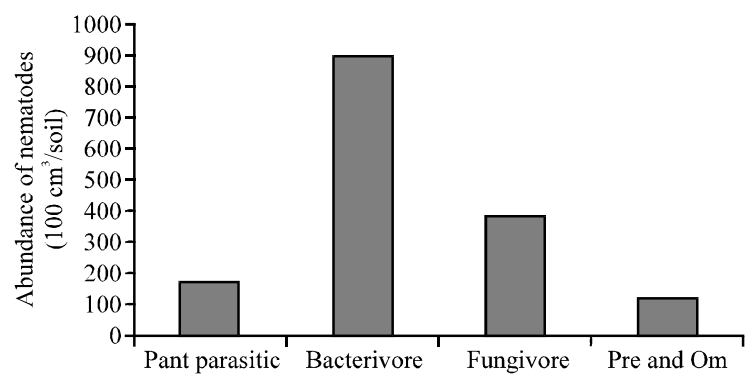

Fig. 2: Nematode trophic groups with their relative abundance

Table 1: Incidence (\%) and range of populations $\left(/ 100 \mathrm{~cm}^{3} /\right.$ soil) of Pratylenchus, Ditylenchus and Meloidogyne sp., associated with potato in the districts

\begin{tabular}{|c|c|c|c|c|c|c|}
\hline \multirow[b]{2}{*}{ Region } & \multicolumn{2}{|c|}{ Pratylenchus sp. } & \multicolumn{2}{|c|}{ Ditylenchus sp. } & \multirow{2}{*}{\multicolumn{2}{|c|}{$\begin{array}{l}\text { Meloidogyne sp. } \\
\text { Incid. (\%) Range }\end{array}$}} \\
\hline & Incid. $(\%)$ & Range & Incid. (\%) & Range & & \\
\hline Aybasti & 100 & $40-180$ & 100 & $20-380$ & 0 & 0 \\
\hline Kabatas & 62.5 & $0-140$ & 75 & $0-260$ & 0 & 0 \\
\hline Korgan & 62.2 & $0-360$ & 100 & $40-180$ & 11.11 & $0-720$ \\
\hline
\end{tabular}

Abun.: Abundance in $100 \mathrm{~cm}^{3}$, Incid.: Rate of presence in samples

\begin{tabular}{|c|c|c|c|c|c|c|c|c|}
\hline \multirow{3}{*}{\begin{tabular}{l} 
Nematodes \\
\hdashline Plant parasitic
\end{tabular}} & \multicolumn{8}{|c|}{ Surveyed districts } \\
\hline & \multicolumn{2}{|c|}{ Aybasti } & \multicolumn{2}{|c|}{ Kabatas } & \multicolumn{2}{|l|}{ Korgan } & \multicolumn{2}{|c|}{ All districts } \\
\hline & Abun. & Incid. & Abun. & Incid. & Abun. & Incid. & Abun. & Incid. \\
\hline Pratylenchus sp. & 108 & 100 & 47 & 62 & 62 & 77 & 70.83 & 79.16 \\
\hline Tylenchus sp. & 17 & 42 & 25 & 50 & 42 & 44 & 29.17 & 45.83 \\
\hline Meloidogyne sp. & 0 & 0 & 0 & 0 & 80 & 11 & 30.00 & 4.16 \\
\hline Helicotylenchus sp. & 0 & 0 & 25 & 50 & 17 & 33 & 14.17 & 29.16 \\
\hline Filenchus sp. & 0 & 0 & 2 & 12 & 8 & 22 & 4.17 & 12.50 \\
\hline Psilenchus sp. & 14 & 42 & 12 & 12 & 6 & 11 & 10.83 & 20.83 \\
\hline Merlinious sp. & 22 & 42 & 5 & 25 & 2 & 11 & 9.17 & 25.00 \\
\hline Tylenchorhynchus sp. & 0 & 0 & 0 & 0 & 2 & 11 & 0.83 & 4.16 \\
\hline Paratylenchus sp. & 0 & 0 & 10 & 37 & 11 & 22 & 7.50 & 20.83 \\
\hline \multicolumn{9}{|l|}{ Bacterivore } \\
\hline Rhabditidae & 334 & 100 & 67 & 87 & 145 & 100 & 162.50 & 95.83 \\
\hline Monhy steridae & 82 & 100 & 77 & 100 & 40 & 66 & 65.00 & 87.50 \\
\hline Cephalobus sp. & 205 & 100 & 135 & 100 & 253 & 88 & 200.00 & 95.83 \\
\hline Eucephalobus sp. & 248 & 100 & 112 & 75 & 80 & 88 & 143.33 & 87.50 \\
\hline Acrobeloides sp. & 348 & 100 & 100 & 87 & 317 & 88 & 254.17 & 91.66 \\
\hline Chiloplachus sp. & 20 & 42 & 2 & 12 & 17 & 44 & 13.33 & 29.16 \\
\hline Cervidellus sp. & 0 & 14 & 2 & 12 & 0 & 0 & 1.67 & 8.33 \\
\hline Acrobeles sp. & 11 & 14 & 0 & 0 & 0 & 0 & 3.33 & 4.16 \\
\hline Wilsonema sp. & 11 & 28 & 0 & 0 & 0 & 0 & 3.48 & 8.33 \\
\hline Plectus sp. & 68 & 71 & 17 & 37 & 53 & 66 & 45.83 & 58.33 \\
\hline Tripyla sp. & 8 & 14 & 2 & 12 & 2 & 11 & 4.17 & 12.50 \\
\hline \multicolumn{9}{|l|}{ Fungivore } \\
\hline Aphelenchoides sp. & 302 & 100 & 187 & 87 & 120 & 77 & 195.83 & 87.50 \\
\hline Aphelenchus sp. & 88 & 85 & 50 & 75 & 117 & 88 & 86.67 & 83.33 \\
\hline Ditylenchus sp. & 151 & 100 & 90 & 75 & 82 & 100 & 105.00 & 91.66 \\
\hline \multicolumn{9}{|c|}{ Predator and Omnivore } \\
\hline Mononchus sp. & 14 & 42 & 32 & 75 & 4 & 22 & 16.67 & 45.83 \\
\hline Dory laimida & 140 & 85 & 100 & 100 & 84 & 77 & 105.83 & 87.50 \\
\hline
\end{tabular}


were $108 / 100 \mathrm{~cm}^{3}$ soil, $62 / 100 \mathrm{~cm}^{3}$ soil, $47 / 100 \mathrm{~cm}^{3}$ soil from Aybasti, Korgan, Kabatas, respectively. Pratylenchus sp., had also the highest number of frequency $(79.16 \%)$ in province scale. In the opinion, this much distribution and abundance may cause some yield reduction agreed with previous studies that concluded sites with high populations of Pratylenchus sp., may reduce yields with time due to the interactions with other pathogens such as Verticillium (Martin et al., 1982; Francl et al., 1987; MacGuidwin and Rouse, 1990). If the genus is identified species as $P$. penetrans, the likelihood would increase. In addition, the stored and infested tubers can initiate a new infestation (Olthof and Wolynetz, 1991). Even if Tylenchus was among the most frequent ones in the survey this group Tylenchus feeds on algae, mosses and lichens (Siddiqi, 2000). In this respect, Tylenchus has no damage potantial on potato. Meloidogyne sp., is another important group and it is known that at least ten of Meloidogyne species infest potatoes (Prasad, 2008). Meloidogyne sp. was found only in a sample in Korgan at $720 \mathrm{~J} 2 \mathrm{~s}$ density for this region. Ozarslandan and Elekcioglu (2010) reported that all samples collected from potato crop in mid-Anatolia were belong to $M$. chitwoodi. If the eggs and juveniles number $/ \mathrm{cm}^{3}$ soil of $M$. incognita exceed 128, this results in $80 \%$ yield loss of tuber (Russo et al., 2007).

Except the nine plant parasitic nematode genera including; Pratylenchus, Tylenchus, Helicotylenchus, Geocenamus, Paratylenchus, Psilenchus, Filenchus, Meloidogyne and Tylenchorhynchus sp., in addition, nine bacterivorus nematode genera including; Cephalobus, Acrobeloides, Eucephalobus, Plectus, Chiloplachus, Tripyla, Cervidellus, Wilsonema and Acrobeles sp. and three fungivorus nematode genera including; Ditylenchus, Aphelenchoides and Aphelenchus sp. were found.

Aphelenchoides sp. (87.5\%) and Aphelenchus sp. $(83.33 \%)$ were in high frequencies of incidence in all regions sampled. These nematodes are known fungal feeders and are not known to cause damage to potato (Al-Hazmi et al., 1993).

\section{CONCLUSION}

To determine nematode assemblages is important in two ways in a given area, first, plant parasitic nematodes are yield limiting factor in crop ecosystems; second, free-living nematodes mostly over-looked in ecosystems are widely accepted as the indicators of soil health. Therefore, researchers covered both components of the nematode fauna in potato growing areas of Ordu province.
In some groups, such as Pratylenchus can damage on potato by the interaction with Verticillium. With this respect, it is very essential to identify nematode groups and to determine their abundances and frequencies of occurence. By this investigation, an important group of nematodes, Pratylenchus was determined in high abundance and frequency of occurience for the major potato producing areas of Ordu province. Fortunately, the most destructive nematode group with a polyphagous nature, Meloidogyne was only found in one locality of the study area. In case of increase of new potato production areas in Ordu, this survey provides a backround for the status of important nematodes. Besides, the study also suggests that free-living nematodes in potato growing areas are divers and abundant enough for an healty ecosystem.

\section{REFERENCES}

Al-Hazmi, A.S., A.A. Ibrahim, A.T. Abdul-Raziq, 1993. Distribution, frequency and population density of nematodes associated with potato in Saudi Arabia. Afro-Asian J. Nematol., 3: 107-111.

Bongers, T., 1990. The Maturity Index: An ecological measure of environmental disturbance based on nematode species composition. Oecologia, 83: 14-19.

Dede, O., 2004. Determination of some agricultural and technological traits of potato varieties in different ripening periods (Solanum tuberosum L.) under Ordu ecological conditions. Ataturk Univ. Faculty Agric. Bull., 35: 159-164.

Demir, N. and E. Kadanali, 2010. An analysis on the production of potato in Turkey according to NUTS level 1 regions. Afr. J. Agric. Res., 5: 1584-1590.

Erdogus, F.D., H.C. Akgul and S. Bayram, 2010. Four new record of species for turkish nematode fauna: Filenchus cylindricus, $F$. sandneri, Lelenchus leptosoma and Geocenamus uralensis. Pak. J. Nematol., 28: 241-251.

Francl, L.J., L.V. Madden, R.C. Rowe and R.M. Riedel, 1987. Potato yield loss prediction and discrimination using preplant population densities of Verticillium dahliae and Pratylenchus penetrans. Phytopathology, 77: 579-584.

Hooper, D.J., 1969. Extraction and Handling of Plant and Soil Nematode. In: Nematodes of Tropical Crops, Peachey, J.E. (Ed.). Commonwealth Bureau of Helminlhology, UK., pp: 20-36.

Jensen, H.J., J.M. Armstrong and P. Jatala, 1979. Annotated Bibliography of Nematode Pests of Potatos. International Potato Center, Lima, Peru, Pages: 315 . 
Misirloglu, B. and E. Ulutas, 2011. Investigation of the fields potentially growing seed potatoes in terms of plant parasitic nematodes in aegean and mediterranean regions. Proceedings of the 4th Plant Protection Congress, June 28-30, 2011, Kahramanmaras, Turkey.

MacGuidwin, A.E. and D.I. Rouse, 1990. Role of Pratylenchus penetrans in potato early dying disease of russet burbank potato. Phytopathology, 80: 1077-1082.

Martin, M.J., R.M. Reidel and R.C. Rowe, 1982. Verticillium dahliae and Pratylenchus penetrans: Interactions in the early dying complex of potato in Ohio. Phytopathology, 72: 640-644.

Mokbel, A.A., I.K.A. Ibrahim, M.A.M. EL-Saedy and S.E. Hammad, 2006. Plant parasitic nematodes associated with some fruit trees and vegetable crops in Northern Egypt. Egypt. J. Phytopathol., 34: 43-51.

Morgan, G.D., A.E. MacGuidwin, J. Zhu and L.K. Binning, 2002. Population dynamics and distribution of root lesion nematode (pratylenchus penetrans) over a three-year potato crop rotation. Agron. J., 94: 1146-1155.

Neher, D.A., 2001. Role of nematodes in soil health and their use as indicators. J. Nematol., 33: 161-168.

Olthof, T.H.A. and M.S. Wolynetz, 1991. Pratylenchus penetrans and $P$. negleclus in tubers of potato (Solanum tuberosum) in Ontario. Can. J. Plant Sci., 71: 1251-1256.

Olthof, T.H.A., 1989. Control of Pratylenchus penetrans on potato with Metam-sodium applied in irrigation water. Suppl. J. Nematol., 21: 693-696.

Ozarslandan, A. and I.H. Elekcioglu, 2010. Identification of the root-knot nematode species (Meloidogyne sp.) (Nemata: Meloidogynidae) collected from different parts of Turkey by moleculer and morphological methods. Turkish J. Entomol., 34: 323-335.
Philis, J., 1997. Effect of cadusafos and carbofuran against Pratylenchus penetrans and some ectoparasitic nematodes infesting potato in Cyprus. Nematol. Medit., 25: 169-172.

Prasad, K.S.K., 2008. Management of potato nematodes: An overview. J. Hortl. Sci., 3: 89-106.

Russo, G., N. Greco, F.P. d'Errico and A. Brandonisio, 2007. Impact of the root-knot nematode, Meloidogyne incognita, on potato during two different growing seasons. Nematol. Medit., 35: $29-34$.

Siddiqi, M.R., 2000. Tylenchida: Parasites of Plants and Insects. 2nd Edn., CABI Publishing, Wallingford, UK., pp: 805.

Vovlas, N., D. Mifsud, B.B. Landa and P. Castillo, 2005. Pathogenicity of the root-knot nematode Meloidogyne javanica on potato. Plant Pathol., 54: 657-664.

Wheeler, T.A., L. V. Madden, R.M. Riedel and R.C. Rowe, 1994. Distribution and yield-loss relations of Verticillium dahlia, Pratylenchus penetrans, P. scribneri, P. crenatus and Meloidogyne hapla in commercial potato fields. Phytopathology, 84: $843-852$.

Yeates, G.W., 1998. Soil nematode assemblages: Regulators of ecosystem productivity. Phytoparasitica, 26: 97-100.

Yeates, G.W., T. Bongers, R.G.M. de Goede, D.W. Freckman and S.S. GeorgIeva, 1993. Feeding habits in soil nematode families and genera-an outline for soil ecologists. J. Nematol., 25: 315-331.

Yildiz, S. and I.H. Elekcioglu, 2011. Nematode biyodiversity in agricultural and natural habitats of Sanliurfa, Turkey. Turk. J. Entomol., 35: 381-394.

Yildiz, S., 2012. Nematode biodiversity in a semi-arid pasture under different grazing regimes. Afr. J. Agric. Res., 7: 414-417. 